\title{
Placement Service at Conference
}

The National Registry for Librarians, in cooperation with the Illinois State Employment Service, is providing placement service during the conference week.

It is suggested that employers in listing their positions, provide adequate descriptions of academic and experience requirements along with position content, opportunities for professional growth, salary, and other benefits.

Applicants should provide adequate details of academic achievement and experience, specifying cities, states, and regions in which employment would be considered, and the minimum acceptable salary.

Employers and employees who registered in advance with the National Registry in Chicago should contact the conference placement center upon arrival at the conference to confirm registrations and to furnish conference addresses. Registrations will also be accepted for those who were unable to register in advance.

The policy of the U.S. Employment Service prohibits the acceptance of a job order which bears discriminatory specifications in respect to race, creed, age, color, sex, or national origin.

The placement center will be open during the following hours:

Monday, June 26, 9:00 a.m.-5:00 p.m.

Tuesday, June 27, 9:00 a.m.-5:00 p.m.

Wednesday, June 28, 9:00 a.m.-5:00 p.m.

Thursday, June 29, 9:00 a.m.-5:00 p.m.

Friday, June 30, 9:00 a.m.-12:00 noon

The placement center will be located in Private Dining Rooms 16, 17, and 18 in the Palmer House.

\section{Allan Nevins Memorial Fund}

The Trustees of the Huntington Library, San Marino, California, have enlisted the aid of noted author and scholar, Irving Stone, to set up a memorial fund in memory of America's greatest historian, Allan Nevins, whose death in 1971 ended an eleven-year association with the library.

The object of the fund is not only to perpetuate the memory of an outstanding scholar and historian, but to continue his surge of creative work at the Huntington Library through the establishment of a permanent senior research associateship in American history, as well as annual fellowships and scholarships or grants for shorter periods of time.

Stone reports that he has been joined by many distinguished people in setting up the fund. Its board of directors, which will operate under his chairmanship, is composed of Elmer Belt, M.D., Edward W. Carter, chairman of the board of Broadway-Hale Stores, Inc., Douglass Cater, author and director, Aspen Institute for Humanistic Studies, Henry Steele Commager, historian and author, The Honorable Alan Cranston, United States Senator, California, Glenn S. Dumke, chancellor, California State University and Colleges, Charles J. Hitch, president, University of California, The Honorable Edward Kennedy, United States Senator, Massachusetts, Clark Kerr, chairman and executive director, Carnegie Commission on High Education, Willard F. Libby, Nobel Laureate, Chemistry, William J. McGill, president, Columbia University, Thomas Reddin, chief of police, Los Angeles (retired), A. L. Rowse, historian and author, Henry J. Seldis, art critic, Los Angeles Times, Millard Sheets, artist and architectural designer, The Honorable John V. Tunney, United States Senator, California, and The Honorable Earl Warren, Chief Justice, United States Supreme Court (retired).

Allan Nevins, a senior research associate at the Huntington Library at the time of his death, March 5, 1971, was generally regarded as the nation's greatest historian. He was a dedicated and prolific scholar, the author and editor of more than one hundred books. His own vivid narratives, and particularly the eight-volume history of the Civil War completed just before his death, The Ordeal of the Union, were packed with excitement and fresh insights. American Heritage magazine was the result of his belief that sound history could be made popular.

Although Nevins was known as an expert on the Civil War, his interests-his books and his years of teaching at Columbia Universityranged over the entire history of the nation, from colonial days to the present.

The present interested Nevins particularly, hence he was confidant and advisor of presidents, from Harry Truman to Eisenhower and Kennedy, and edited President Kennedy's speeches for publication. He was also the father of the Oral History Program, now in nationwide use, to record for future historians the views of today's greats and near-greats. 